\title{
Towards Safeguarding Rural Communities' Social and Economic Interests Through Communal Property Law
}

\author{
Werner Schoeman \& Mashele Rapatsa \\ University of Limpopo, School of Law, Polokwane, SOUTH AFRICA
}

Received: 28 May 2021 • Accepted: 23 August 2021 • Published Online: 16 September 2021

\begin{abstract}
South Africa's incessant Corporate Law Reforms do offer vast opportunities for rural communities to be actively involved in their own social and economic development. This article discusses the practicability of using a private company to promote and develop social and economic interests of rural communities. The fundamental question is: what constitute proper administration and socio-economic development in a rural context? It takes into account, the fact that the post-1994 democratic dispensation has made some effort to develop and strengthen the constitutional property rights, and the social and economic development of the previously disadvantaged rural communities. This encompassed the idea of, somewhat, relying on civil society institutions to manage and develop property rights of rural communities. Nonetheless, it should be noted that the success thereof is dubious since the development and operation of civil society institutions in these communities are constantly under threat and undermined by the tenacity of conflicts between administrators and the traditional leadership. It is asserted that there is an incessant need to resolve fundamental aspects relating to law, application of legal norms and achievement of social justice in a rural context.
\end{abstract}

Keywords: communal property interests, corporate law reform, socio-economic development, rural development, constitutional transformation.

\section{Introduction}

Although underutilized in a rural community context, South Africa's corporate law has evolved so tremendously that it is unavoidably necessary to explore the possibility of relying on a private company to promote and develop socio-economic property interests of rural communities. This is particularly significant in the context of advancing such constitutional transformative ideals that emanated from corporate law reform, which amongst others, sought to inculcate improved governance, accountability and sustainability in the corporate world. Despite all the above mentioned constitutional, corporate and property law developments, many problems still prevail in the management of property of rural communities, necessitating the exploration of alternatives. One such a possibility is the use of a private company to promote and develop the economic and property interests of rural communities as an alternative institution to enhance transparency, higher standards, democracy and the protection of human rights in communal context.

Section 7 of the Companies Act 71 of 2008 provides that the Companies Act seeks to encourage the growth of the South African economy by encouraging private enterprise and

(C) Authors. Terms and conditions of Creative Commons Attribution 4.0 International (CC BY 4.0) apply. Correspondence: Mashele Rapatsa, University of Limpopo, School of Law, Department of Public and Environmental Law, Polokwane, SOUTH AFRICA. E-mail: mashele.rapatsa@ul.ac.za. 
business efficiency, by also generating suppleness and simplicity in the creation and preservation of companies. However, it should be noted that there has been an increasing resistance against Western developmental theories which were employed during the early developmental phases of African democracies. Therefore, within this context, we posit the question whether the countermodernist approach could have a positive impact on the development of rural development, in an African democratic context. This article explores this question in relation to the development of property law which safeguards the social and economic interests of rural communities, and more precisely the concept of property in common, as referred to in South Africa's Communal Property Associations Act 28 of 1996 or community property, as referred to in the Communal Property Associations Amendment Bill, as published in Government Gazette No. 40772 of 7 April 2017.

\section{Problem statement, rationale and methodology}

Disputes and internal conflict as well as conflicting interest amongst Communal Property Association (CPA) members, Communal Property Association Committees and their members, Communal Property Associations and Traditional Authorities and Communal Property Associations and the rural communities have been prevalent over the years (Dept. of Rural Development and Land Reform, 2012). It has been argued that these problems arose from maladministration by CPA executive committees, poor governance, misappropriation of funds and property (Pienaar, 2009: 24).

Against the above backdrop, this article is aimed at illustrating that private companies may be used to develop and improve the effective management of properties of rural communities, and thus foster sustainable social and economic development of such communities. At the center of attention, the article describes shareholders as community members who should accordingly contribute towards the development of the field of property law and the general protection of the constitutional rights of rural communities in South Africa. The article proffers a new scope of new thinking in law in as far as it deals with a novel doctrine suggesting new thinking in the application of company law to enhance the property interests of rural communities, specifically as a result of constitutional development of property rights and company law developments in general.

The ultimate objective of this article is to illustrate that the traditional model of relying on community representatives in the form of traditional leaders of the community has not yielded the desired outcomes. Further that although the Communal Property Associations Act 28 of 1996 endeavors to create "appropriate legal institutions" for disadvantaged communities to acquire and manage common property, there are still challenges. Therefore, to ensure the protection of members amongst themselves from abuse of power, these institutions should be managed in a non-discriminatory, equitable and democratic way with accountability to their members as stipulated in its preamble, an ideal which is practicably achievable using a private company. A combination of both doctrinal approach and theory based analysis were adopted as methodological tools. This method is best suited because normative doctrines, founded in the Constitution of the Republic of South Africa, 1996 (hereinafter, the Constitution) and Companies Act 71 of 2008 provides guidance in terms of what is legally and constitutionally reasonable and justiciable, and can be used to best explain social and economic circumstances that inform social and legal policies. In the main, the article shall demonstrate why a private company is best suited for serving the developmental social and economic interests of rural communities.

\section{Theoretical framework}

The need for order and efficiency caused a shift from the prominence on Western-style democracy, as the wisdom for development, to a counter-modernist approach in development in the late 1960s. It was believed by scholars, that the problems faced by poorer countries were less 
their traditional attitudes and more the imprudent mixing of political participation with established weakness, in accumulation of the decadent waste of resources. Political participation also remained a laudatory objective. Regardless of copious foreign aid, and, even in rapidly growing industrialized states, such as South Africa, rates of economic growth remained unimpressive and long-term prospects for social equality appeared deplorable. This forced an internal re-evaluation of the concepts and theories contained within the existing modernization framework, which resulted in the counter-modernist developmental theory (Manzo, 1991: 27). The assumption that poorer countries are interested in procuring Western qualities such as independence, progress, political involvement, judiciousness and modern presumptuousness, was stated as a fact. Hence, the "Participatory Action Research" philosophy emerged as a result of the rethinking by academics, social movements and leading practitioners of development projects.

\subsection{Participatory action research philosophy}

During the 1970s, the questions on how to create widely held control, instead of economic growth and how to empower people to obtain control over the powers that determine their lives, was central to the Participatory Action Research philosophy. The Participatory Action Research philosophy merge techniques of political involvement, adult education and research in social science, with a foundation of denunciation of the Western abstract of "top to down" development plans, which endeavor to universalize experience. It further inspires local grassroots ingenuities, with emphasis on the necessity for economic processes that are both endowed in the needs of particular communities and fitting for the local ecologies. Prominence is sited to probe into what development denotes to poor and marginalized people. Consequently, development should cease to be done to people and should rather be done by the people, developing into a participating process where people are empowered to determine the making of their own communities. Development theory should become more an exchange of ideas between researcher and subject rather than a prologue from subject to object. As an alternative of telling people in poorer countries what it is and how to get it, researchers should rather listen to what the people say about their own development (Manzo, 1991: 28).

As a result, the partitions between subject and object, research and practice, and the empiricist social science and Western philosophy, dictating what is acceptable and what is not, should be rejected. Science will be considered as the result of a process in which theory-building and the prevalent civil service for change are combined and become part of the same historical progression. It will endeavor to exceed the boundaries of present philosophy by acknowledging the differences, without being internally obliged to define most differences as forms of dissimilarity to be conquered or assimilated (Ibid.). Richard Peet and Michael Watts (1993) argue that the post-structural theory, which obtained its popularity in the deconstruction of the Western mythologies of science, truth, and rationality, has also constructed a mythology about the contention and has taken the "dialectic of Stalin's iron laws of history" as its fundamental model. It is depicted as an "idealist device in which thesis incorporates anti-thesis to an already-given synthesis, allowing no room for contingency, difference, or, for that matter, the new." It is their opinion that "dialectical analysis", as an alternative, offers the opportunity of conjuring up a system of relations that does not consume the independence of the specific, and in which various vibrant trends, in moving categorized measures, are frequently upset by a new series of diverse actions. A dynamic with "pattern, order, and determination without being teleological, a theory of totalities which, because it values their unique aspects, is not totalizing". This prolonged conception of discussions provides a way of comprehending the compound forms of environmental inconsistencies and social engagements (Peet \& Watts, 1993: 248-249). Manzo (1991: 30) expresses his opinion as follows: "What is needed now is for social theory to take seriously the ideas of those who argue for grounding knowledge in local histories and experiences, 
rather than building theory through the use of general conceptual categories and Western assumptions."

Since the 1960 s several counter-modernist developmental theories have seen the light and it is not a new phenomenon. Ruth Jebe (1993) focuses on the practices that produce reporting structures, rather than the reporting frameworks and reason that the South African New Governance process offer a better methodical framework for generating added vigorous sustainability reporting systems than those of the traditional regulatory approaches. She argues that the New Governance Theory (NGT) postulates situations where traditional government regulations are less effective as a means to achieve public objectives (Jebe, 2015: 238). NGT identifies situations where other forms of regulation, including increased civilian contributions and decentralized policymaking, are more likely to accomplish the expected result (Lester, 2002). Dissatisfaction with government commanded reporting requirements inspired many countries to investigate alternative methods for fashioning corporate reporting regimes. South Africa is recognized as a world leader in moving forward in the discipline of sustainability reporting, which is a direct result of a counter-modernist approach to development. Since 2009, listed companies on the Johannesburg Securities Exchange (JSE), are required by the JSE to produce an annual "integrated" sustainability report. This requirement serves as a condition for listing on the JSE. In line with the requirements of The King Code of Corporate Governance Principles for South Africa, listed companies are compelled to produce an integrated report for financial years beginning on or after 2010. Although it may seem unexpected that this innovation in sustainability reporting come from South Africa, rather than from developed countries, such as the European Union or the United States. Evidently the exploiting of NGT's in South Africa's diminishes the role of top-down government regulation (Jebe, 2002).

The 1980's signaled a new chapter in the discourse on means of governing, when the precincts of command-and-control regulation became progressively more ostensible. The bureaucratic, hierarchical, top-down, state-centric, regulatory administrative state, was founded on the supposition of exclusive knowledge and proficiency of the expert policymakers. Oblivious from public demand and pressure governments established administrative agencies to enhance their command and control. Government prescribed prescriptive standards (commanded) and their administrative agencies monitored and enforced the standards (controlled) to attend to the private and organized welfare of bureaucrats (Salmon, 2002).

The Corporate Communal Development Theory (CCDT), as a social development theory, which considered the acknowledged wisdom of those who reason for basic knowledge in local histories and practices without comparison to colonial hegemony was introduced in the discussion of the Communal Property Associations Act and the Companies Act in the discourse on the use of a private company to promote and develop the property interests of rural communities (Schoeman, 2018). It is argued that the Communal Property Associations Act is an example of a counter-modernist approach that has acknowledged the resident antiquities of communities desiring to own and manage communal property without association to the Western concept of private property and that the development of the Companies Act was a result of the requisite for legislation to comply with the country's Constitution.

4. Deconstruction of the Western mythologies of science, truth and rationality in Property Law

When South Africa became a democratic state in 1994, a new dispensation was born in developmentalism, coerced by the Constitution. Before 1994, any development in law and society, was driven by Western philosophies, engrained with colonialism. Improvement and prosperity were measured by the success in achieving or not achieving Western objectives. The criticism of Western science as wisdom in its pure and entire essence, opens the door for a better 
appreciation of the diverse methods to grasp the development-environment relationship. Exploration commences with concrete criticism on the destructive environmental corollaries of modernity and contend for context-reliant and considerably dissimilar indigenous discourses about development. The post-structural criticism of the cogent, pinpoints the links between natural science and imperialism. It allows for a recovery of country-dweller and ethnic discourses on land use and management, which enhances the prospect for an exchange of information (Peet \& Watts, 1993).

\subsection{Ownership in land in South Africa's context}

Section 1 of the Communal Property Association Act 28 of 1996 defines property as, "property" includes movable and immovable property and any right or interest in and to movable or immovable property or any part thereof. Judge Yacoob stated in Government of the Republic of South Africa v Grootboom 20011 SA 46 (CC) para 22, that the comprehension of rights to property should be done within the sociological and historical perspective. It follows that in order to understand ownership in land or any other right or concern in and to either movable or immovable property in the correct context, reflection should first be given to the historical development of ownership in South Africa. In the South African law, the perception of ownership originates primarily from the Roman Dutch law. The Roman Dutch law constitutes ownership as a real right in property with acknowledgment of certain restrictive conditions that may be registered against the title of the property. These registered conditions will place a perimeter on the enforcement of the real right in the property by the owner (Van der Merwe, 1989). Ownership in property has developed in the South African law to be concomitant with real rights, which in broad terms inaugurates an absolute and exclusive right in property (Pienaar, 1986:1). Such right in property is superior to any other rights.

Property legislation of the past was based on racial discrimination. The result was that majority of South African communities were excluded to own property rights in land. More than a century ago oppressive legislation embarked with the Natives Land Act 27 of 1913 shadowed by the Native Trust and Land Act 18 of 1936 and crowned with the Group Areas Act 41 of 1950. This was trailed by the Group Areas Act 36 of 1966, which completed the Group Areas Act 41 of 1950. The intention of the government of the day was to consolidate the law relating to the establishment of group areas with the aspiration of regulating the control over and the acquisition of immovable property. This also included the regulation of occupation of land.

It was obligatory to repeal these oppressive acts in order to generate fair and equal opportunities for all South African citizens to acquire ownership in land, and to accomplish more equality in the distribution of land ownership (Kloppers \& Pienaar, 2014). Eventually the Abolition of Racially Based Land Measures Act 108 of 1991 was promulgated to revoke or modify laws to eradicate constraints based on race diversity for the acquisition and utilization of various rights to land and to arrange for the phasing out of institutions founded on race. Section 12 of the Abolition of Racially Based Land Measures Act 108 of 1991 contained transitional measures to phase out the South African Development Trust. This Trust was the registered owner of the majority of communal land, which needed to be transferred back to the rural communities from whom this land was unjustly dispossessed off.

Consequently, it was followed by the introduction of the Reconstruction and Development Programme with the aim of:

“... eradicating the legacies of the past through the redress of inequalities and building a vibrant and democratic South Africa...acknowledged that land represented the most basic need for the rural population, a need that resulted from the discriminatory practices of the past regime. In order to effectively address the issues of inequality, poverty and landlessness caused by the "injustices of forced 
removals and the historical denial of access to land" the program identified the need for the establishment of a comprehensive national land reform program" (Kloppers \& Pienaar, 2014: 688-89).

In 1997, the purpose of the White Paper on Land Policy was to create a land reform policy and addressing the historical injustices (Dept. of Land Affairs White Paper on Land Policy, 1997). Its purpose is further described "...to provide an overall platform for land reform consisting of three principal components: restitution, redistribution and tenure reform," which were the matching pillars, identified in the Reconstruction and Development Programme.

\section{The constitutional property clause}

Although it is not the aim of this study to investigate the constitutionality of property rights, acknowledgment should be given to the current status of property. For the sake of completeness, it is necessary to consider the recent developments in constitutional property rights since it affects all property, which will of course also include any property or interest in property of rural communities

Van der Walt (2004) considers the question whether certain interests will qualify as property and then extensively compares the property clause, as contained in section 25 of the Constitution, with the German private law. He examines property being the object of property rights, property as property rights and property as a restricted right and then summarizes the German position regarding non-proprietary rights as follows (Van der Walt, 2000):

\footnotetext{
"In accepting that non-proprietary rights can also qualify as property for purposes of the constitutional guarantee, the German courts rely on the fundamental guideline mentioned earlier: a right will be in- or excluded from the property concept according to the question whether the in- or exclusion will serve the creation of the sphere of personal freedom which will allow the individual person to take responsibility for the development and management of her own affairs within the social context. On the basis of this test, certain non-proprietary rights (and particularly the socially extremely important land-use rights of residential lessees and lessees of garden allotments, as well as the participatory rights of employees in a large firm, and the claim rights of beneficiaries of a socially important compensation fund for victims of a pregnancy drug) has been included in the property guarantee, while others (especially some social participatory rights and some claim rights) have been excluded."
}

This functional and purposive approach requires that a court will have to apply a balancing of interests in each individual case. In analyzing the Port Elizabeth Municipality v Various Occupiers case 2005 (1) SA 217 (CC) para 8-23, Van der Walt (2011) concludes that there is a shift in the thinking of property rights in general, as being abstract and rights-based to a contextual, non-ranked philosophy about property rights. Pienaar has as far back as 1986 already resolved that: Although the South African concept of ownership is basically derived from the Roman and Roman Dutch concepts, it is not in every way comparable to the latter because of changed social, political, economic, religious and philosophical factors. The said factors often make it necessary to introduce new developments, which influence the concept of ownership.

In Van der Walt's (2011) discussion of the First National Bank of SA Ltd t/a Wesbank v Minister of Finance 2002 (4) SA 768 (CC), he confirmed that the Constitutional Court has repeatedly indicated that a purposive approach is appropriate when the Bill of Rights should be interpreted. Van der Walt observed that since $\mathrm{n}$ 1997, the Constitutional Court has indicated that the property clause will definitely be approached from a purposive perspective and that the clause needs to be construed with due regard to its constitutional devotion and historical perspective. This approach has been confirmed in the recent Bakgatla-Ba-Kgafela Communal Property 
Association case. ${ }^{1}$ Whether the law should be changed and non-proprietary rights treated equally, being absolute rights, together with vested real rights in property, or whether the court should apply a balancing act between property and non-proprietary rights, does not fall within the scope of this study, except to note that despite the Roman Dutch inheritance, the courts have recognized and applied the principle that there is no fixed number of real rights and have found that non-real rights, which burden real rights should be registered against the property because of its intimate connection with the property concerned (Carey Millar, 2000). It is further clear from section 25(4)(b) of the Constitution that for purposes of section 25, property is not limited to land, as also unanimously confirmed by Jafta $\mathrm{J}$ in the Bakgatla-Ba-Kgafela Communal Property Association case, where he states that: In section 25(7), the Constitution recognizes and protects rights in land which go beyond registered ownership. Van der Walt (2011) shares this opinion in his discussion of eviction from property, where he points out three matters to be considered when interpreting property legislation and the common law development of property. Firstly, an order should be justified in light of the circumstances. Secondly, a balancing exercise, between the rights of the landowner and interests of the occupiers should be done, despite the fact that the interests of the occupiers do not amount to property, as historically understood. Thirdly, a balancing exercise should be done between the permanent and continuing effects of the historical background and the current situation.

Van der Walt concludes that it could be argued that the contextualized-balancing principle could be expanded beyond the scope of eviction, resulting in punier rights not being hypothetically oppressed by stronger rights. The constitutional property concept has developed to include interests in property that would not have been recognized as property, prior to the Constitution and these interests may now compete on the same level with conflicting property rights. It is thus evident that rights in land go further than real rights and will also include nonreal rights or interests associated with land or the use of land. This opens the door for the long overdue recognition of traditional values in the interpretation, applying and enforcing of traditional rural communal rights. Consideration should likewise be given to the exceptional limitation of rights, as contained in section 36(1) of the Constitution, which allow for rights in the Bill of rights to "be limited only in terms of law of general application, to the extent that the limitation is reasonable and justifiable in an open and democratic society, based on human dignity, equality and freedom, taking into account all relevant factors, including: (a) the nature of the right; (b) the importance of the purpose of the limitation; (c) the nature and extent of the limitation; (d) the relation between delimitation and each purpose; and (e) less restrictive means to achieve the purpose."

\section{Traditional ownership}

Pienaar (1986) compares the concept of ownership in a socialist community with those in a traditional primitive communal society and differentiate the two from each other, on the basis of control and ownership or absence of control and ownership by the state, as well as the existence or absence of the profit motive. The main distinction lies in the fact that in a traditional community communal property ownership vest in a particular family while in a socialist's community, communal property belongs to the state. The Rural Women's Action Research Programme at the Centre for Law \& Society of the University of Cape Town refers to this concept of communal ownership as African freehold and states that valuable lessons need to be learned from the practice of African freehold ownership. They recommend that the customary values and

${ }^{1}$ The full citation and details of the case are thus, Bakgatla-Ba-Kgafela Communal Property Association v Bakgatla-Ba-Kgafela Tribal Authority and Others [2015] ZACC 25 para 35; Department of Land Affairs and Others v Goedgelegen Tropical Fruits (Pty) Ltd [2007] ZACC 12; 2007 (6) SA 199 (CC); 2007 (10) BCLR 1027 (CC) at para 53 . 
understanding and practices of African freehold ownership should, rather be adhered to than following Western legislation, which is based on exclusive ownership. This will ensure that family interests of rural communities are protected. Ironically, it is then suggested that: "Urgent additions are that protected rights must be recorded and registered, so that they cannot be sold from under people, and people have the security of written proof of their rights." Thus, creating an anomaly, since the formal act of registration of ownership in land originates from Western tradition of registering rights in property.

A better understanding of rural communities' interpretation and enforcing of rights are well illustrated in the case study done by Michael Schnegg and Theresa Linke at the University of Hamburg in Germany (Schnegg and Linke, 2015):

"In sum, the case studies indicate that social networks hinder formal sanctioning and at the same time adjust and substitute enforcement rules. Since they are substituted, institutions work, and water is provided. It is difficult to say whether the causal relationships observed here will also hold true for the management of other common-pool resources, like pastures, forests or fisheries. From what we observe, we would assume that under similarly high levels of density, connectedness will always be challenging to execute specific sanctions in small face-to-face communities."

A much more tolerant approach and gradual intensifying of social pressure to enforce the community's rights against an individual who does not comply with the rules and expectations of the community, exists in rural communities. This approach differs considerably from the less tolerant Western approach to the immediate enforcement of social or individual rights against offenders.

\section{Communal ownership}

Section 1 of the Communal Property Association Act defines the holding of property in common to mean the acquisition, holding and management of property by an association on behalf of its members, in accordance with the terms of a constitution. This definition implies a representative relationship, and the relationship is confirmed to be a fiduciary relationship in terms of section 8(7), section 9(e)(vi) and section 14(1)(b) of the Communal Property Association Act. In terms of section 8(2)(a), one of the qualification requirements for the registration of a Communal Property Association, obliges the adopted constitution to dispense with the issues stated in the Schedule. Item 4 of the Schedule refers to "land or property to be owned by the association" and item 7 only refers to members' rights to use the association's property.

Although property is defined, as being movable and immovable property, specific reference to the acquiring of land is made on only three occasions in the act, of which one is by way of implication. The provisions of the Communal Property Association Act apply to communities that are eligible for restoration of land, legalized by the Restitution of Land Rights Act 22 of 1994 where the Land Claims Court has made an order of restitution on condition that a Communal Property Association be established. Secondly, reference is made, in section 2(1)(b) CPA Act, to disadvantaged communities approved by the Minister of Rural Development and Land Reform who acquired land or rights to land and who desires to form a Communal Property Association. Thirdly, reference is made to identified land or the right to land to be acquired by a provisional association when it applies for registration.

The only reference made to the registration of land in the name of a Communal Property Association, is where the Minister of Rural Development and Land Reform is authorized to determine that the provisions of laws ruling the establishing of towns and the Subdivision of Agricultural Land Act 70 of 1970 will not be applicable to land which is registered in the name of 
a Communal Property Association. This is concurrent with the concept of a Communal Property Association being a juristic person, existing apart from its members. Members of the association therefore do not become the registered owners of land but are only entitled to the use of land owned by the Communal Property Association. In slight contradiction to the above mentioned, item 9 of the Schedule alludes to rights and property of a member on termination of membership and item 10 outlines the purposes for which property may be used, the physical partition thereof, and apportionment of property to different members. This may create the impression that members individually become owners of parts of the communal property. It is imperative that traditional and communal ownership should be defined properly without changing the original concept thereof. Without this comprehension all attempts to regulate traditional or communal ownership, in terms of western regulation legislation will dwindle, since current legislation do not provide for proper recognition and implementation of traditional ownership.

In contradiction to the findings of Van der Walt, Pienaar $(2008,1)$ compares the South African Rictersveld Case with the Delgamuukw cases in Canada and focus on the elementary differences, being embedded in the range of inclusivity or the exclusivity of land tenure, also referred to as a discourse of exclusion and in the dissimilarity between the idea of property urged by individualism and the institution of property engrossed with concession, rationality and the strain between the individual and communal interests. Pienaar chooses Canada to compare the inclusivity or exclusivity of property since both countries have fused communal land tenure in their property law. In South Africa the property law is primarily of civilian nature while Canada mainly follows a common law approach. Civil law and common law principles are recognized by both countries respectively, which includes the Roman-Dutch concept of exclusivity of ownership, being a comprehensive real right a person can have, in relation to property within the limitations of the law in general. Although private ownership is constitutionally protected in our law, the case First National Bank of SA Ltd t/a Wesbank v Commissioner, South African Revenue Services 2002 4 SA 768 (CC) para 51. See also President of the RSA v Modderklip Boerdery (Pty) Ltd 2005 SA 3 (CC), has ascertained that it is limited in the public interest.

According to Pienaar (2008), the common law principle on land tenure followed in Canada is considered to be less complete and is suppler than the strict Roman-Dutch concept. The Crown holds supreme ownership of all the immovable property in the country while the tenants only have land tenure rights in the form of interests, tenures and estates. Different land tenure rights can therefore be exercised by several people in respect of the same property. This modest form of ownership or freehold ownership found in Canada is often observed as absolute ownership of the land, or at least, as close to being absolute owner as English common law permits. To a large degree, land tenure rights in Canada also appear to be exclusive in nature, excluding other persons from the rights of usage and possession of land.

Communal land rights are exercised by indigenous communities and presents qualities of social relationships (household and kinship networks with different forms of community membership); inclusive, rather than exclusive in character, are shared and relative but in general secured (in one particular community rights can be individualized, communal like grazing and fishing or mixed like seasonal cropping events); the community's land ethos gives certain access to land (The norms and values of the communities determine social rights, rather than authoritative and administrative structures to control access to land); rights originates from putative membership (membership from of a particular social unit and is attained through birth, allegiance, relationship or dealings); Social and political boundaries (mark out the use of resources and are generally straight forward, frequently malleable and negotiable but also a cause for strain and skirmish); bendable balance of power (amongst gender role, contending communities, tenures, land administration authorities and traditional authorities); intrinsic negotiability and flexibility of land tenure rights (allows for rights to adapt to changing conditions but also make it 
vulnerable to acquisition by dominant external forces like the government or susceptible to capital investors).

The invariable goes for attempts to regulate rural communities with existing traditional authorities descending from the apartheid era. As long as there is resistance from communities against established authorities, none of the rules and regulations implemented by these authorities will be honored by community members. For any attainment, the land reform program has to be elongate and feasible. The constant ignorance towards both economic and social sustainability in the redistribution and the restitution pillars of the land reform programs contributed considerably to most of the envisioned agricultural land being unproductive (Kloppers \& Pienaar, 2014).

\section{Diverging economic interests}

Internal conflicts and struggles for control and management of Communal Property Association's is a result of pre-existing tribal authorities which are referred to as traditional councils in terms of the Traditional Leadership and Governance Framework Amendment Act 23 of 2009. Section 3(2)(b) of this Act requires pre-existing tribal authorities to comply with two transformation measures. The first, is that forty percent of traditional council members have to be democratically elected and secondly, that one third of traditional council's members must be women. The time frame for meeting these requirements, which was one year, had to be extended several times. It is now clear that pre-existing tribal authorities are not willing to share their power, especially not with woman. According to the Rural Women's Action Research Programme at the University of Cape Town, many councils still do not comply with the women's quota and where elections were held it was mostly flawed. Even 10 years later, there has not been traditional council elections in Limpopo. The situation is so out of hand that the new Traditional Affairs Bill was supposed to come to the rescue by repealing the Traditional Leadership and Governance Framework Amendment Act and thereby introduce new provisions to contend with the consequences of non-compliance of traditional councils. It is however unlikely that the bill will ever be implemented due to constitutional issues. Disputes and internal conflict, as well as conflicting interest amongst Communal Property Association members, Communal Property Association Committees and their members, Communal Property Associations and Traditional Authorities and Communal Property Associations and the rural communities seems to be the order of the day. Top this with maladministration by Communal Property Association executive committees, poor governance, misappropriation of funds and property and the parties will indefinitely end up with litigation where the conflicts have been protracted.

And indeed, it ensued in a classic example, illustrated in the Bakgatla-case, where the members of the community favored a Communal Property Association, while the tribal authority and the traditional leader, Kgosi Pilane, preferred a trust to advance the community's property rights. Even after referral of their dispute to the Minister of Rural Development and Land Reform, who suggested the registration of a provisional Communal Property Association to enable the parties to decide the issue within the period of twelve months, being the time, as allowed by the Communal Property Association Act, the dispute could not be resolved. Neither was the BakgatlaBa-Kgafela Communal Property Association registered as a permanent Communal Property Association.

The diversity of duties and responsibilities of the Director-General cannot be over emphasized. Save to say that the Communal Property Association Act not only empowers but requires the Director-General to play an active role in solving disputes between the leaders and the community. In the Bakgatla-case, the Director-General did not attend to the registration process in the spirit, as expected by the Communal Property Association Act. He resisted the Communal Property Association's registration without attempting to assist the community, and 
his conduct was capricious with the recommendation made by his own delegate. The DirectorGeneral showed an indecorous reaction to the community's lawful request for registration of a Communal Property Association. Not only did the Director-General obstruct the Bakgatla-BaKgafela community's endeavors to register a Communal Property Association but also, collectively with the Minister of Rural Development and Land Reform, opposed the relief sought by the community.

The fact that the legislature gave recognition to traditional councils does not remove the communities' view and resistance towards traditional leaders, who are seen as an extension of the British colonialist's dictatorship. Customary systems of land rights do not comprise of property rights for their members, but allow for misuse by the autocratic power of traditional leaders. Evidently the non-compliance with the Traditional Leadership and Governance Framework Amendment Act raises doubt over traditional leaders' legal capacity to own the land that belongs to the rural community. Consequently, most traditional councils are not legally constituted and therefore have not acquired the legal capacity to own or transfer land. For the same reason, traditional councils do not have the legal status to procure investment transactions. Traditional leaders, on the other hand, are concerned about the wearing down of their seat of power by communities who refuse to further recognize their traditional councils (Pienaar, 2009).

In an application for leave to appeal against a decision of the Supreme Court of Appeal, the legality of a decision of the Department of Mineral Resources to award Genorah Resources (Pty) Ltd prospecting rights on the Bengwenyama community's land was decided. ${ }^{2}$ The Bengwenyama community was dispossessed of their land during apartheid but successfully instituted a land claim and the land was subsequently returned to the Bengwenyama community. During the same time that the respondent, Genorah Resources (Pty) Ltd, applied for a prospecting right on the same land. The Bengwenyama community, making use of a company called Bengwenyama Minerals (Pty) Ltd also applied for a prospecting right. The company was specifically registered for the purpose of acquiring the prospecting rights on behalf of the Bengwenyama community. Despite the initial concern of the Department of Mineral Resources, and their advice to the community to procure better protection in the investment agreement, the community's application was simply ignored by the department. The court found that the Department of Mineral Resources failed to comply with the requisites for consultation and with its duty to give Bengwenyama Minerals (Pty) Ltd an opportunity to apply for a preferent prospecting right.

The Mineral and Petroleum Resources Development Act 28 of 2002 was promulgated not only to give effect to the constitutional norms of equality, dignity and freedom, but also to substantially impact on individual and communal ownership of land and the empowerment of previously disadvantaged persons to gain access to mineral resources. Consequently, section 104 of the act allows previously disadvantaged communities to apply for and be granted a preferential prospecting right in relation to other applicants. It is perplexing that the second respondent was the Minister for Mineral Resources, the third respondent the Director-General of Mineral Resources, the fourth respondent the regional manager of the department of Mineral Resources, Limpopo Region, and the fifth respondent was the deputy Director-General of the department of Mineral Resources. All are representatives of the government of South Africa opposing an application brought by a previous disadvantaged rural community seeking justice against an unlawful decision by the Department of Mineral Resources. Mostert (2014) resolved that:

"The problem is that no land reform venture of the scale embarked on in South Africa can even remotely hope to meet the targets set within one generation, let alone a few

2 Bengwenyama Minerals (Pty) Ltd and Others v Genorah Resources (Pty) Ltd and Others 2011 (4) SA 113 (CC) A par 3. 
election cycles. Although land reform is highly politicized, it is, unfortunately, not an area in which real solutions fit political expediency."

\section{Conclusion}

This article has illustrated that various reasons may exist to justify the believe that Communal Property Associations (CPAs) are not progressively suitable as entities that can best manage communal property and socio-economic interests of rural communities. However, the reality is that more than one thousand and two hundred communities are aligned with this concept of property management, which confirms their trust in the management style, as proposed by the Communal Property Associations Act. It has been noted that much of the denunciation for the critics against Communal Property Associations can be laid at the door of the Department of Rural Development and Land Reform. Much of the frustration experienced by communities is directly linked to lack of knowledge and incapacity of government institutions, including the legislature's inadequate capabilities to draft properly guided legislation. Therefore, this article concludes that indeed the emphasis should, rather be on the administrative measures to establish tenure security for communities and groups in a transparent and an accountable way (Pienaar, 2009: 28). Apposite legislation, which is akin to the codification of management regulations, as found in the Companies Act is essential to empower and assist communities to take command of the management of their property to the advantage of every member of the community. This approach is consistent with the counter-modernist approach and could have a positive impact on the social and economic development of rural communities in an African democratic setting.

\section{Acknowledgements}

This research did not receive any specific grant from funding agencies in the public commercial, or not-for-profit sectors. It was developed from the dissertation of W. Schoeman, supervised by M. Rapatsa, passed in 2018 at the University of Limpopo.

The authors declare no competing interests.

\section{References}

Carey Millar, D. (2000). A land title in South Africa. Cape Town: Juta Publishers.

Department of Rural Development and Land Reforms, 2011/2012 Annual Report 80. Land Affairs (1997). White Paper on Land Policy.

Kloppers, H., \& Pienaar, G. J. (2014). The historical context of land reform in south africa and early policies. Potchefstroom Electronic Law Journal, 17(2), 676-706.

Jebe, R. (2015). Sustainability reporting and new governance: South Africa marks the path to improved corporate disclosure. Cardozo Journal of International and Company Law, 23(2), 233-293.

Salamon, L. M. (ed.) (2002). The tools of government: A guide to the new governance. Oxford University Press.

Peet, R., \& Watts, M. (1993). Introduction: Development theory and environment in an age of market triumphalism. Economic Geography, 69(3), 227-253.

Pienaar, G. (1986). Ontwikkelings in die Suid-Afrikaanse Eiendomsbegrip in Perspektief. Journal of South African Law (TSAR), 3(1), 295-308. 
Pienaar, G. (2008). The inclusivity of communal land tenure: a redefinition of ownership in Canada and South Africa? Electronic Journal of Comparative Law, 12(1), 1-17.

Pienaar, G. (2009). Aspects of land administration in the context of good governance. Potchefstroom Electronic Law Journal, 12(2), 15-55.

Pienaar, G. (2009). Regulating communal land rights: The story continues. Journal for Contemporary Roman-Dutch Law (THRHR), 72(1), 1-16.

Schnegg, M., \& Linke, T. (2015). Living institutions: Sharing and sanctioning water among pastoralists in Namibia. World Development, 68, 205-214.

Schoeman, W. (2018). The use of a private company to promote and develop the property interests of rural communities. LLM dissertation, University of Limpopo.

Van der Merwe, C. G. (1989). Sakereg. Durban: Butterworths Publishers.

Van der Walt, A. J. (2000). Civil forfeiture of instrumentalities and proceeds of crime and the constitutional property clause. South African Journal on Human Rights, 16(1), 1-45.

Van der Walt, A. J. (2004). Striving for the better interpretation - A critical reflection on the Constitutional Court's Harksen and FNB decisions on the property clause. South African Law Journal, 121, 854-866.

Van der Walt, A. J. (2011). Constitutional property law. Cape Town: Juta Publishers. 
W. Schoeman \& M. Rapatsa - Towards Safeguarding Rural Communities' Social...

C O A $\mathbf{s}$ 